\title{
An Adult Choledochocele Case Presented with Acute Pancreatitis: Treatment by Endoscopic Sphincterotomy and Cyst Unroofing
}

\section{To the Editor:}

Choledochocele is a cystic dilatation of the intraduodenal portion of the common bile duct that can protrude into the duodenum. Although often classified as type III biliary cyst, choledochocele has distinctive demographic and anatomic features, and is associated with a lower risk of malignancy as compared to other types of choledochal cysts. Patients with this condition present with biliary colic, cholangitis, or pancreatitis. ${ }^{1,2}$ Until recently, transduodenal cyst excision with or without sphincterotomy had been the treatment of choice. ${ }^{3}$ At present, however, endoscopic sphincterotomy and cyst unroofing have become the treatment of choice. ${ }^{4}$ We present a case of choledochocele associated with acute pancreatitis that was treated with endoscopic sphincterotomy and cyst unroofing.

A 38-year-old woman with a 24-hour history of severe abdominal pain, nausea, and vomiting was admitted to our clinic. On physical examination, mild upper abdominal tenderness was observed. On admission, her amylase level was 3,262 IU/L (reference range, 25 to 125 ) and her C-reactive protein level was $64 \mathrm{mg} / \mathrm{dL}$ (reference range, 0 to 0.8 ). Transabdominal ultrasonography and magnetic resonance cholangiopancreatography (MRCP) revealed a dilated main pancreatic duct, mild peripancreatic fluid collection, and a cystic lesion 4 $\mathrm{cm}$ in diameter that was localized to the second portion of the duodenum. Furthermore, MRCP revealed that the cyst had the same intensity as the biliary tract and that the cyst communicated with the main pancreatic duct and common bile

Received: December 30, 2014 Revised: January 3, 2015 Accepted: March 19, 2015

Correspondence: Remzi Beştaş

Department of Gastroenterology, Diyarbakir Education and Research Hospital 21010, Diyarbakir, Turkey

Tel: +90-53-2773-5176, Fax: +90-41-2248-8523, E-mail: bestasr@gmail.com

(c) This is an Open Access article distributed under the terms of the Creative Commons Attribution Non-Commercial License (http://creativecommons.org/ licenses/by-nc/3.0) which permits unrestricted non-commercial use, distribution, and reproduction in any medium, provided the original work is properly cited. ducts (Fig. 1). Duodenoscopy revealed a soft and pedicular mass covered with normal duodenal mucosa, approximately

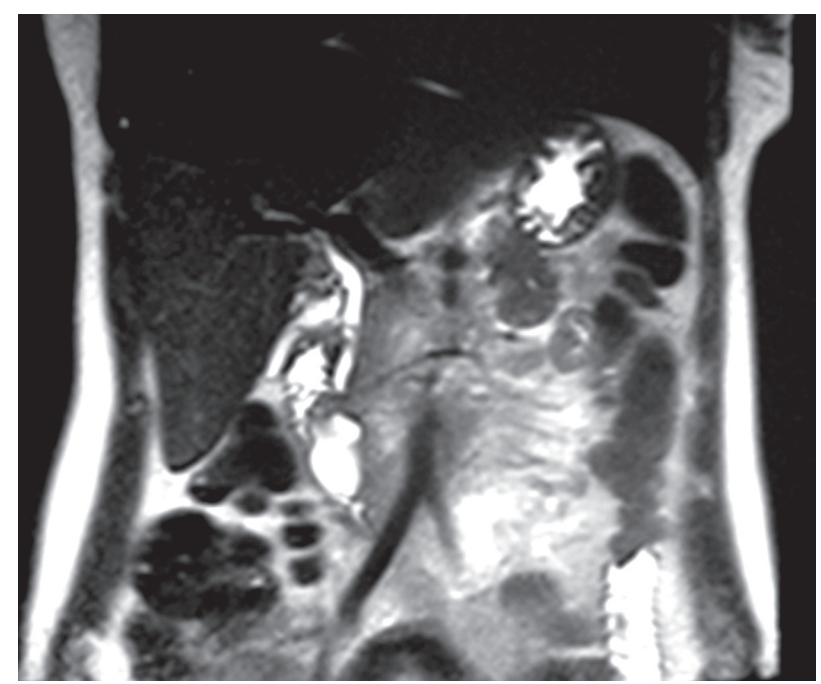

Fig. 1. A magnetic resonance cholangiopancreatography image showing that the cyst had the same intensity as the biliary tract and that the cyst communicated with the main pancreatic duct and common bile duct.

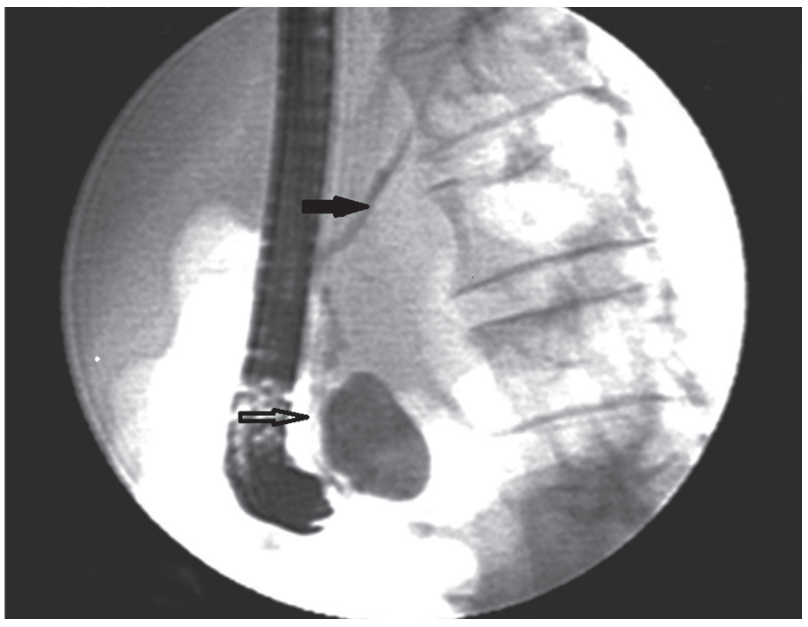

Fig. 2. An endoscopic retrograde cholangiopancreatography image showing communication between the cystic dilatation of the intraduodenal common bile duct (white arrow) and the pancreatic duct (black arrow). 
$4 \times 3 \times 3 \mathrm{~cm}$ in size, in the medial wall of the duodenum. Cholangiography revealed an intraduodenal cyst communicating with the common bile duct and main pancreatic duct (Fig. 2). The patient had no other symptoms during the 6-month follow-up.

In conclusion, choledochocele should be considered as a differential diagnosis of duodenal cystic lesion. Endoscopic unroofing may be considered as a simple and safe treatment option for choledochocele.

Conflicts of Interest

The authors have no financial conflicts of interest.

\section{Remzi Beştaş ${ }^{1}$, Nazım Ekin ${ }^{2}$, Feyzullah Uçmak and Muhsin Kaya ${ }^{2}$}

${ }^{1}$ Department of Gastroenterology, Diyarbakir Education and Research Hospital, Diyarbakır, ${ }^{2}$ Department of Gastroenterology, Dicle University School of Medicine, Diyarbakır, Turkey

\section{REFERENCES}

1. Khandelwal C, Anand U, Kumar B, Priyadarshi RN. Diagnosis and management of choledochal cysts. Indian J Surg 2012;74:29-34.

2. Jabłońska B. Biliary cysts: etiology, diagnosis and management. World J Gastroenterol 2012;18:4801-4810.

3. Can MF, Kaymakçioğlu N, Yağci G, Görgülü S, Tufan T. An adult choledochocele case presented with gastric outlet obstruction: a rare presentation. Turk J Gastroenterol 2006;17:70-73.

4. Law R, Topazian M. Diagnosis and treatment of choledochoceles. Clin Gastroenterol Hepatol 2014;12:196-203. 